\title{
PRECONCENTRATION, DETERMINATION AND SPECIATION OF IRON BY SOLID-PHASE EXTRACTION USING DIMETHYL (E)-2-[(Z)-1-ACETYL)-2-HYDROXY-1-PROPENYL]-2-BUTENEDIOATE
}

\author{
Gholamreza Khayatian*, Shahed Hassanpoor, Farough Nasiri and Amin Zolali \\ Chemistry Department, Faculty of Science, University of Kurdistan, Sanandaj, Iran
}

Recebido em 2/6/11; aceito em 24/9/11; publicado na web em 6/12/11

\begin{abstract}
A new sensitive and selective procedure for speciation of trace dissolved $\mathrm{Fe}(\mathrm{III})$ and $\mathrm{Fe}(\mathrm{II})$, using modified octadecyl silica membrane

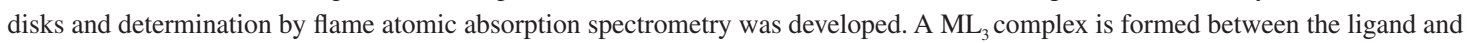
$\mathrm{Fe}$ (III) responsible for extraction of metal ion on the disk. Various factors influencing the separation of iron were investigated and the optimized operation conditions were established. Under optimum conditions, an enrichment factor of 166 was obtained for $\mathrm{Fe}^{3+}$ ions. The calibration graph using the preconcentration system for $\mathrm{Fe}^{3+}$ was linear between 40.0 and $1000.0 \mu \mathrm{g} \mathrm{L}^{-1}$.
\end{abstract}

Keywords: speciation; iron; solid-phase extraction.

\section{INTRODUCTION}

Iron is the fourth most abundant element (after $\mathrm{O}, \mathrm{Si}$, and $\mathrm{Al}$ ) and second most abundant metal on the earth's crust. It plays aa prominent role in chemical reactions, such as in geological processes, environmental and atmospheric chemistry, and in biochemistry. ${ }^{1}$ The environmental and biological effectiveness of iron depends, to a large extent, on its chemical properties, such as valence, solubility and the degree of complex formation. Iron plays an important role in plant metabolism where it is essential for photosynthetic and respiratory electron transport, nitrate reduction, chlorophyll synthesis and detoxification of reactive oxygen species. ${ }^{2-5}$ Owing to the presence of iron in environmental and biological materials, and the lack of sufficient understanding of the role of the two oxidation states of this element, determination of both $\mathrm{Fe}(\mathrm{II})$ and $\mathrm{Fe}(\mathrm{III})$ is of great importance. ${ }^{6-8}$

The speciation of iron(III) and iron(II) has been studied by different techniques such as electrothermal vaporization inductively coupled plasma optical emission spectrometry (ETV-ICP-OES), polarography, ${ }^{9,10}$ flow injection analysis, ${ }^{11}$ voltammetry, ${ }^{12}$ atomic absorption spectroscopy (AAS), ${ }^{13}$ and capillary electrophoresis. ${ }^{14}$ The lower concentration of this element relative to the detection limits of the instruments used, together with sources of interfering effects from the matrix of the real samples, are two main difficulties involved in these determinations..$^{15}$ In order to overcome these difficulties, enrichment/separation methods including solvent extraction, cloud point extraction and solid-phase extraction have been commonly used for sample pre-treatment. ${ }^{16}$

Solid phase extraction (SPE) is an attractive technique that reduces solvent usage and exposure, disposal cost and extraction time for sample preparation., ${ }^{4,13-21}$ Various solid-phase extraction materials including Duolite XAD 761, ${ }^{19}$ Dowex optipore V-493, ${ }^{15}$ microcrystalline naphthalene. ${ }^{20}$ Sepiolite ${ }^{21}$ and $\mathrm{Al}_{2} \mathrm{O}_{3}$ nanoparticles ${ }^{4}$ have been used for the extraction and determination of iron species.

In the present study, a solid phase extraction method was developed for the speciation and determination of iron in different water samples using the new ligand dimethyl (E)-2-[(Z)-1-acetyl)2-hydroxy-1-propenyl]-2-butenedioate (DAHPB) to retain the iron prior to detection by flame atomic absorption spectrometry (FAAS).

*e-mail: gkhayatian@yahoo.com

\section{EXPERIMENTAL}

\section{Reagents}

Extra pure methanol, acetonitrile (AN), nitric acid, trimethylamine (solution 50\% w/w in water), dimethyl acetylenedicarboxylate, acetylacetone, and hydrochloric acid were used as received from Merck. The standard solution of iron(III) (1000 $\left.\mathrm{mg} \mathrm{L}^{-1}\right)$ was from Merck, and iron(II) stock solution (1000 $\left.\mathrm{mg} \mathrm{L}^{-1}\right)$ was prepared by dissolving of $\mathrm{Fe}\left(\mathrm{NH}_{4}\right)\left(\mathrm{SO}_{4}\right)_{2} \cdot 6 \mathrm{H}_{2} \mathrm{O}$ in water and adjusting the $\mathrm{pH}$ to 1.0 by adding $\mathrm{HCl}$ accordingly.

\section{Synthesis of ligand}

Trimethylamine solution $\left(2.36 \times 10^{-2} \mathrm{~g}, 50 \% \mathrm{w} / \mathrm{w}\right.$ in water, $0.20 \mathrm{mmol}$ ) in $1 \mathrm{~mL} \mathrm{CH}_{2} \mathrm{Cl}_{2}$ at $0.0^{\circ} \mathrm{C}$, was added, drop wise to a stirred solution of dimethyl acetylenedicarboxylate $(0.28 \mathrm{~g}, 2 \mathrm{mmol})$ in $2 \mathrm{~mL}$ $\mathrm{CH}_{2} \mathrm{Cl}_{2}$, for $5 \mathrm{~min}$. Acetylacetone $(0.20 \mathrm{~g}, 2 \mathrm{mmol})$ in $1 \mathrm{~mL} \mathrm{CH}_{2} \mathrm{Cl}_{2}$ was then added drop wise to the solution at $0.0^{\circ} \mathrm{C}$ for $5 \mathrm{~min}$. The reaction mixture was then allowed to warm up to room temperature and was stirred for $2 \mathrm{~h}$. The solvent was removed under reduced pressure and the product was obtained as a brown oil. IR $\left(\mathrm{KBr}, \mathrm{v} / \mathrm{cm}^{-1}\right)$ : 3435,1719 , and $1631 ;{ }^{1} \mathrm{H} \mathrm{NMR}\left(250.1 \mathrm{MHz}, \mathrm{CDCl}_{3}\right): \delta=1.84\left(\mathrm{~s}, 6 \mathrm{H}, 2 \mathrm{CH}_{3}\right), 3.64$ and $3.73\left(2 \mathrm{~s}, 6 \mathrm{H}, 2 \mathrm{OCH}_{3}\right), 6.99(\mathrm{~s}, \mathrm{CH}), 16.45(\mathrm{~s}, \mathrm{OH}) ;{ }^{13} \mathrm{C} \mathrm{NMR}$ $\left(62.9 \mathrm{MHz}, \mathrm{CDCl}_{3}\right): \delta=23.3\left(2 \mathrm{CH}_{3}\right), 52.0$ and $52.8\left(2 \mathrm{OCH}_{3}\right), 106.8$, 131.8, and 139.7 (3 C), 164.9 and 166.5 (2 CO, ester), 189.8 (2 CO).

\section{Instrumentation}

The determination of iron and other cations were performed on a Shimadzu AA-670 atomic absorption spectrometer (Kyoto, Japan) under the recommended conditions for each metal ion. The wavelength used to detect iron was $248.3 \mathrm{~nm}$ and bandwidth was $0.2 \mathrm{~nm}$. All $\mathrm{pH}$ measurements were performed using an Metrohm E-691 digital $\mathrm{pH}$ meter with a combined glass electrode. Spectrophotometric measurements were take using a Carry $1 \mathrm{E}$ dual beam spectrophotometer with a $1 \mathrm{~cm}$ glass cell. A mol ratio measurement was done with a Metrohm 662 photometer at $482 \mathrm{~nm}$. Conductance measurements were carried out using a Metrohm 712 conductometer. A dip-type conductivity cell made of platinum black, with a cell constant of $0.832 \mathrm{~cm}^{-1}$ was used. For all measurements, the cell was thermostated at $25.0 \pm 0.1{ }^{\circ} \mathrm{C}$ using an MLW thermostated-circular water bath as described elsewhere. ${ }^{22-25}$ 


\section{General extraction procedure}

Extraction was performed using Empore membrane disks (3 M Co., St. Paul, MN, USA); $47 \mathrm{~mm}$ diameter, $0.5 \mathrm{~mm}$ thick with $90 \%$ octadecyl-bonded silica ( $8 \mu \mathrm{m}$ particle, $60 \AA$ pore size) and $10 \%$ PTFE fiber. The disk was used in conjunction with a standard Millipore 47 mm filtration apparatus connected to a vacuum pump. In order to remove potential interferences and to ensure optimal extraction of the analyte of interest, the recommended disk cleaning and conditioning were performed before use. After placing the membrane disk in the filtration apparatus, $10 \mathrm{~mL}$ methanol was poured onto the disk and immediately drawn through it by applying a slight vacuum. After all the solvent had passed through the disk, it was dried by passing air through it for a few minutes. The disk conditioning was then begun by pouring $10 \mathrm{~mL}$ methanol onto the disk, applying a low vacuum, and letting the solvent surface almost reach the surface of the disk, without allowing the disk to soak without vacuum, nor allowing air to come into contact with the disk surface. A DAHPB solution $(9 \mathrm{mg}$ in $5 \mathrm{~mL}$ acetonitrile) was then introduced onto the disk and drawn slowly through the disk using a vacuum. Finally, the disk was washed with $25 \mathrm{~mL}$ of water and dried by passing air through it.

The general procedure for the speciation of iron on the membrane disk was as follows. The modified disk was first washed in $0.5 \mathrm{~mL}$ methanol followed by $25 \mathrm{~mL}$ buffer solution with the same $\mathrm{pH}$ as the sample solution. The appropriate volume of iron(III) and iron(II) sample solution (adjusted to $\mathrm{pH} 2.5$ with $\mathrm{HCOOH}, \mathrm{NaCOOH}$ ) was passed through the membrane. After the extraction, the disk was fully dried by passing air through it for a few minutes. The extracted iron(III) was stripped from the membrane disk using $9 \mathrm{~mL}$ of $0.1 \mathrm{~mol} \mathrm{~L}^{-1}$ EDTA. The eluted solution was collected in a test tube and then measured by flame atomic absorption spectroscopy.

\section{RESULTS AND DISCUSSION}

\section{Absorbance spectra}

To investigate the possibility of DAHPB as a suitable ligand for speciation of $\mathrm{Fe}(\mathrm{III})$ and $\mathrm{Fe}(\mathrm{II})$, interaction of this ligand with different metal cations was studied spectrophotometrically at aqueous solutions. The results of the experiments are shown in Figure 1.

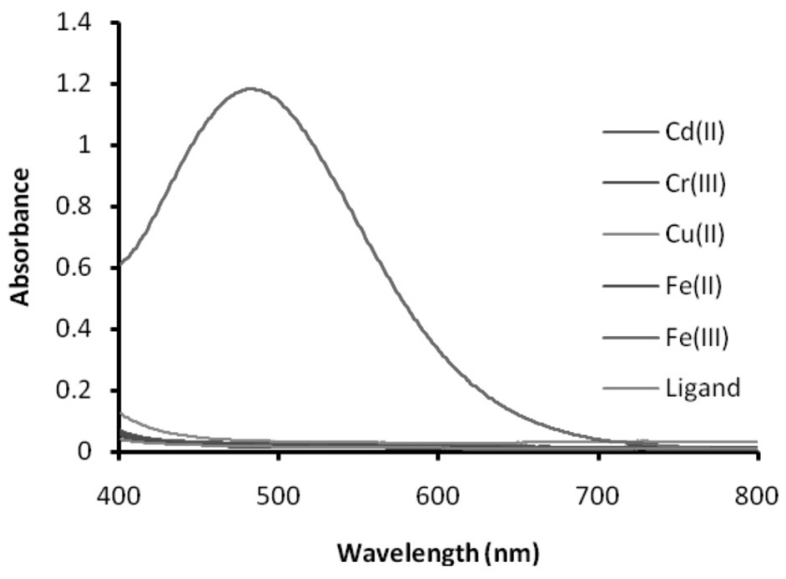

Figure 1. UV-visible absorption spectra of different metal cations with DAHPB in aqueous solution $\mathrm{pH} 2.5$ adjusted with $\mathrm{HCOOH}-\mathrm{NaCOOH}$

As can be seen from Figure 1 iron(III) formed a red complex with DAHPB that absorbed at $\lambda_{\max }=482 \mathrm{~nm}$, while iron(II) and the other tested cations did not form any color complexes. These results indicate that DAHPB may be a selective complexing agent for determination and speciation of iron in the presence of other metal ions. The stoichiometry of the Fe(III)-DAHPB complex was determined by absorbance measurements at $\lambda_{\max }=482 \mathrm{~nm}$. The stoichiometry was determined to be 1:3 $\left(\mathrm{ML}_{3}\right)$ using both the mole ratio method (Figure 2a) and continuous variation (or job's) method (Figure 2b).
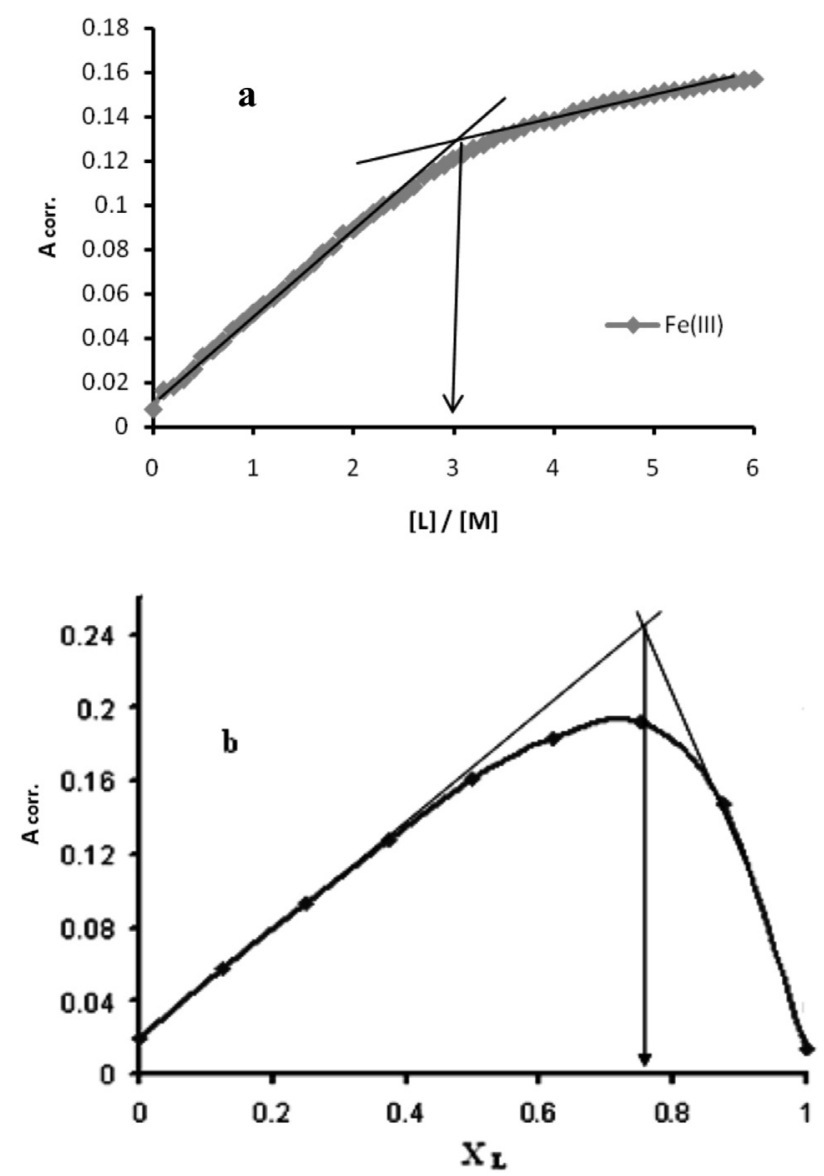

Figure 2. Mole ratio method (a), and (b) Job's method for stoichiometry determination of complex at $482 \mathrm{~nm}, X_{L}$ is mole fraction of ligand the condition: (a) $\left[\mathrm{Fe}^{3+}\right]=1 \times 10^{-3} \mathrm{~mol} \mathrm{~L}^{-1},[\mathrm{DAHPB}]=1 \times 10^{-4} \mathrm{~mol} \mathrm{~L}^{-1}, \mathrm{pH}=2.5$, (b) condition: $\left[\mathrm{Fe}^{3+}\right]=[D A H P B]=1 \times 10^{-3} \mathrm{~mol} \mathrm{~L}^{-1} ; \mathrm{pH}=2.5: \lambda_{\max }=482 \mathrm{~nm}$

\section{Conductimetric titration}

Complex formation of the DAHPB with $\mathrm{Fe}$ (III) and $\mathrm{Fe}$ (II) ions in AN was also investigated using conductance measurements at $25^{\circ} \mathrm{C}$. The resulting molar conductance vs. DAHPB to Fe(III) or Fe(II) mole ratio plots, are shown in Figure 3.

In the cases studied, addition of ligand to the Fe(III) ion solution caused a continuous increase in molar conductance of the solution, indicating a higher mobility of complexed $\mathrm{Fe}$ (III) ion in comparison to the solvated cation. It is clear from Figure 3 that the slope of the corresponding mole ratio plot changes sharply at the point where the ligand-to-cation mole ratio $=3$, indicating the formation of a $1: 3$ complex $\left(\mathrm{ML}_{3}\right)$. However, in the case of $\mathrm{Fe}(\mathrm{II})$ ion, addition of the ligand to the solution does not cause any considerable change in slope, even at a ligand $\mathrm{Fe}(\mathrm{II})$ ion mole ratio of 4 . This behavior probably indicates that complexes cannot form between them. Thus, based on the results discussed above, the following reaction mechanism is suggested as that responsible for the extraction and speciation of $\mathrm{Fe}^{3+}$ ions. The structure of the complex is shown in Figure 4.

$\mathrm{Fe}^{3+}(\mathrm{aq})+3 \mathrm{DAHPB}($ solid phase $) \leftrightarrows \mathrm{Fe}(\mathrm{DAHPB})_{3}($ solidphase $)+3 \mathrm{H}^{+}(\mathrm{aq})$ 


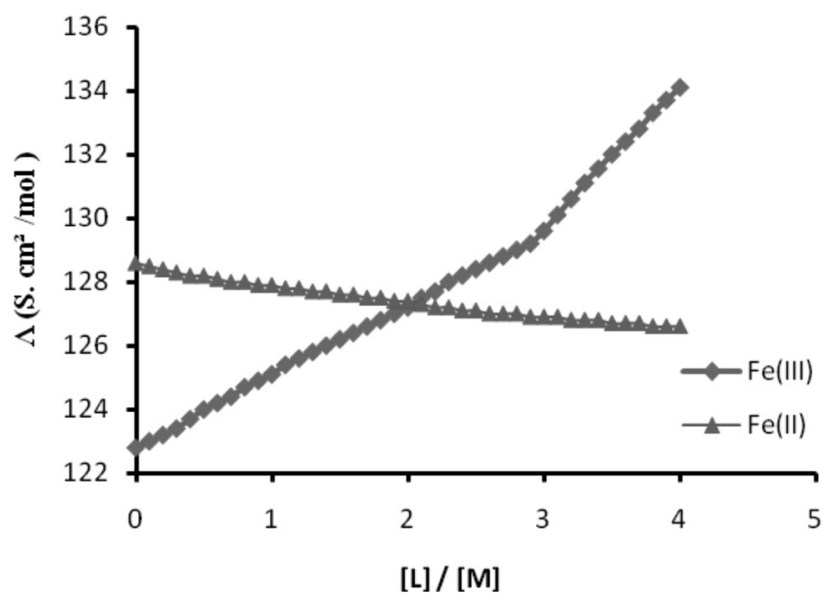

Figure 3. Molar conductance vs [L]/[M] for DAHPB - $\mathrm{Fe}^{3+}$ and DAHPB $-\mathrm{Fe}^{2+}$ systems in AN solution. $X_{L}$ is mole fraction of the ligand<smiles>C=C=CC(=O)OC(C)=C(C(C)=O)C(C)=O</smiles>

Figure 4. Structure of the complex

\section{Effect of amount of DAHPB}

The amount of ligand is an important parameter to obtain quantitative recovery. For this reason, the amount of ligand was tested in the range of 0-12 mg. As shown in Figure 5, quantitative recoveries were obtained when the ligand amount was higher than $8 \mathrm{mg}$. Accordingly a $9 \mathrm{mg}$ of the ligand was used in all experiments.

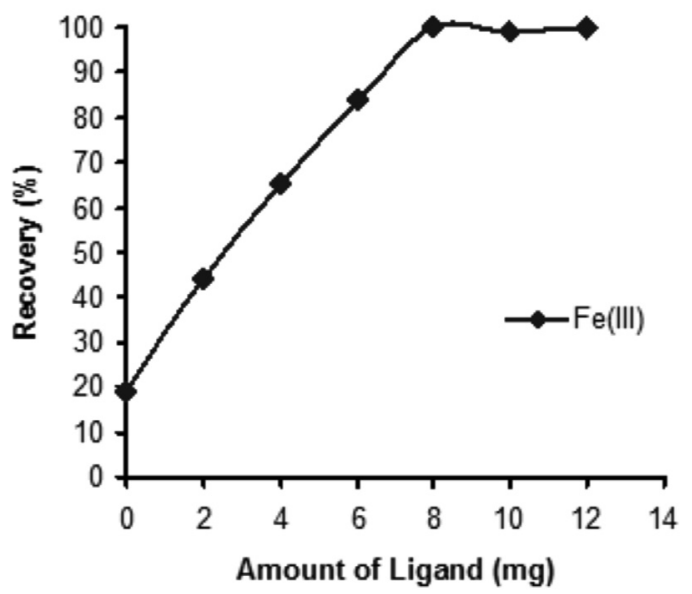

Figure 5. Effect of the amount of ligand on the percent of recovery of $\mathrm{Fe}(\mathrm{III})$, sample volume: $100.0 \mathrm{~mL}$, amount of $\mathrm{Fe}^{3+}$ is $50.0 \mu \mathrm{g}, \mathrm{pH}=2.5$

\section{Effect of pH on speciation of Fe (III) and Fe (II) ions}

$\mathrm{pH}$ is another important parameter for extraction studies. Much of the selectivity achieved in this extraction depends on adequate control of $\mathrm{pH} .{ }^{26,27}$ The effect of $\mathrm{pH}$ of aqueous phase on extraction recovery was studied by applying the proposed procedure to the sample solution. The $\mathrm{pH}$ of each solution was adjusted to values ranging from 1 to 7 with $\mathrm{HNO}_{3}$ and/or $\mathrm{NaOH}$ solutions. The results are given in Figure 6, showing the recoveries of $\mathrm{Fe}(\mathrm{III})$ were quantitative $(>95 \%)$ in the $\mathrm{pH}$ range of 2.4-7.0, while $\mathrm{Fe}$ (II) was not quantitatively recovered at all $\mathrm{pH}$ levels. These results show that iron(II)'s complex cannot form between ligand and $\mathrm{Fe}$ (II) ions. However, some adsorption of $\mathrm{Fe}(\mathrm{II})$ ion at higher $\mathrm{pH}$ values $(>2.7)$ is due to silanol groups $(\mathrm{Si}-\mathrm{OH})$ on the surface of the disk, which tend to retain iron(II) ions from the solution. Thus in all subsequent studies for the separation/preconcentration of Fe(III), a $\mathrm{pH} 2.5$ was used where $\mathrm{pH}$ adjustment in each sample was carried out by sodium formate/formic acid buffer solution.

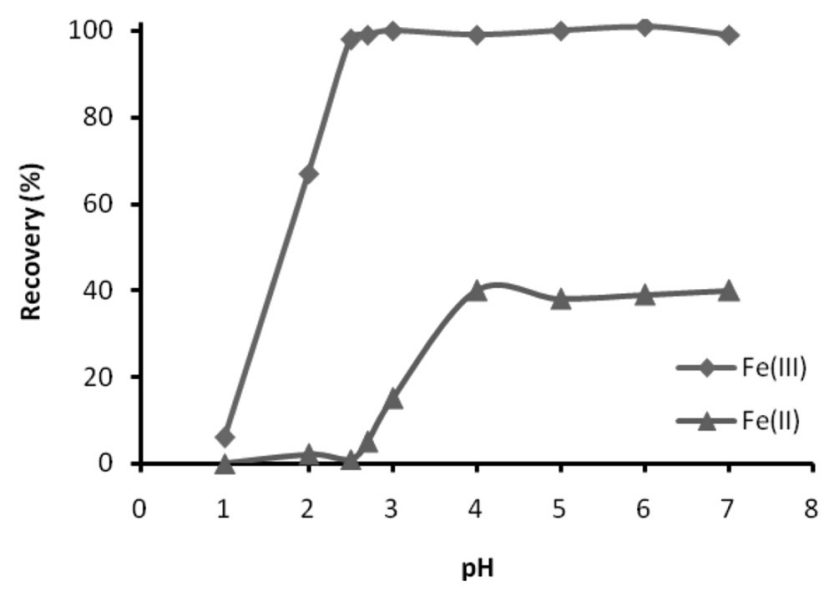

Figure 6. Effect of $p H$ on percent of recovery of $\mathrm{Fe}^{2+}$ and $\mathrm{Fe}^{3+}$ sample volume: $100.0 \mathrm{~mL}$ containing $50.0 \mu \mathrm{g}$ of $\mathrm{Fe}^{3+}$ and $\mathrm{Fe}^{2+}$ ions

\section{Effect of type and concentration of eluent}

Various inorganic acids and EDTA were used to identify the best eluent for adsorbed Fe (III) ions on the modified disk. The results are shown in Table 1. Among the different eluents used, $9 \mathrm{~mL}$ of $0.1 \mathrm{~mol} \mathrm{~L}^{-1}$ EDTA provided the highest recovery. Therefore, this solution was chosen as an eluent for further study.

Table 1. Effect of various eluents on the recoveries of the analyte $(\mathrm{N}=3)$

\begin{tabular}{lc}
\hline Type of eluent & Recovery of Fe(III) $(\%)$ \\
\hline $5 \mathrm{~mL}$ of EDTA $0.1 \mathrm{~mol} \mathrm{~L}^{-1}$ & $80.0 \pm 0.8^{\mathrm{a}}$ \\
$9 \mathrm{~mL}$ of EDTA $0.1 \mathrm{~mol} \mathrm{~L}^{-1}$ & $99.0 \pm 1.1$ \\
$10 \mathrm{~mL}$ of EDTA $0.1 \mathrm{~mol} \mathrm{~L}^{-1}$ & $99.0 \pm 1.2$ \\
$9 \mathrm{~mL}$ of $\mathrm{HNO}_{3} 0.1 \mathrm{~mol} \mathrm{~L}^{-1}$ & $94.0 \pm 1.2$ \\
$10 \mathrm{~mL}$ of $\mathrm{HNO}_{3} 0.1 \mathrm{~mol} \mathrm{~L}^{-1}$ & $98.0 \pm 1.6$ \\
$10 \mathrm{~mL}$ of $\mathrm{HNO}_{3} 0.01 \mathrm{~mol} \mathrm{~L}^{-1}$ & $13.0 \pm 2.6$ \\
$10 \mathrm{~mL}$ of $\mathrm{HCl} 0.1 \mathrm{~mol} \mathrm{~L}^{-1}$ & $76.0 \pm 1.7$ \\
$10 \mathrm{~mL}$ of $\mathrm{HCl} 0.01 \mathrm{~mol} \mathrm{~L}^{-1}$ & $9.0 \pm 1.2$ \\
\hline
\end{tabular}

a Mean \pm standard deviation.

\section{Effect of flow rate of sample solution and eluent}

The effect of flow rates of the sample solution on the recovery of Fe (III) and Fe (II) were also investigated in the range of 2-14 $\mathrm{mL} \mathrm{min}^{-1}$. The results showed iron(III) was quantitatively recovered in range of 2-8 $\mathrm{mL} \mathrm{min}^{-1}$, while $\mathrm{Fe}$ (II) was not retained on the disk for the whole range of flow rates tested. Therefore, a flow rate of $7 \mathrm{~mL} \mathrm{~min}{ }^{-1}$ was applied for analytes.

The flow rate of eluent solution was also examined in the range of 0.5-5.5 $\mathrm{mL} \mathrm{min}^{-1}$ and the results showed maximum recovery for $\mathrm{Fe}(\mathrm{III})$ was obtained in the range of $0.5-2.5 \mathrm{~mL} \mathrm{~min}^{-1}$. Consequently, a flow rate of $2 \mathrm{~mL} \mathrm{~min}^{-1}$ was chosen as the optimum value. 


\section{Effect of $\mathrm{Fe}(\mathrm{II}) / \mathrm{Fe}(\mathrm{III})$ ratios}

In order to study the range of applicability of the proposed method it was necessary to investigate the effect of $\mathrm{Fe}(\mathrm{II}) / \mathrm{Fe}$ (III) ratios from 0:10 to 10:0. Results of this investigation are given in Figure 7.

As seen in Figure 7, the recoveries of $\mathrm{Fe}(\mathrm{III}), \mathrm{Fe}(\mathrm{II})$ and total Fe were not affected even when the mole ratio of $\mathrm{Fe}(\mathrm{II}) / \mathrm{Fe}(\mathrm{III})$ changed from 0:10 to 10:0, and all recoveries were in the range of $95-100 \%$.

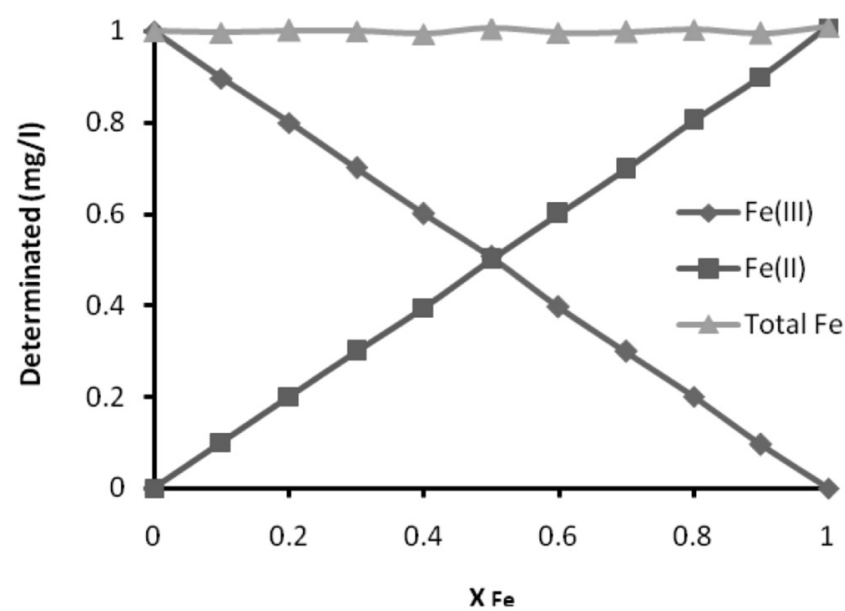

Figure 7. Effect of different ratios of $\mathrm{Fe}^{3+} / \mathrm{Fe}^{2+}$ on the recovery of $\mathrm{Fe}^{2+}, \mathrm{Fe}^{3+}$ and total $\mathrm{Fe}$, sample volume: $100.0 \mathrm{~mL}, \mathrm{pH}=2.5 . \mathrm{X}_{\mathrm{Fe}}$ : mole fraction of $\mathrm{Fe}$

\section{Interference study}

The influence of foreign ions which interfere with determination of analyte ions by the presented method in various environmental samples was examined. In this experiment, solutions of $50.0 \mu \mathrm{g} \mathrm{L}^{-1}$ of $\mathrm{Fe}(\mathrm{III})$ and $\mathrm{Fe}$ (II) and added interfering ions were treated according to the recommended procedure. Results are given in Table 2. The recoveries of analytes were grater than $95 \%$. Tolerable limit was defined as the highest amount of foreign ions that produced an error not exceeding 5\%. As shown in Table 2, the presence of major cations and anions had no obvious influence on the determination of $\mathrm{Fe}$ (II) and $\mathrm{Fe}(\mathrm{III})$ under selected conditions.

\section{Breakthrough volume and enrichment factor}

In order to investigate the breakthrough volume, sample solutions of $25,50,100,500,1000$ and $1500 \mathrm{~mL}$ containing $50.0 \mu \mathrm{g} \mathrm{Fe}(\mathrm{III})$ were passed through the column, and then treated according to the recommended procedure. It was found that $\mathrm{Fe}$ (III) could be quantitatively retained in all cases. Thus, the breakthrough volume of the method must be greater than $1500 \mathrm{~mL}$. As described in the previous section, the elution volume for $\mathrm{Fe}$ (III) was $9 \mathrm{~mL}$, therefore an enrichment factor of 166 for $\mathrm{Fe}(\mathrm{III})$ could be obtained in this work.

\section{Precision, limit of detection and maximum capacity}

Precision was measured for a series of 10 independent determinations containing $0.5 \mathrm{mg} \mathrm{L}^{-1}$ of $\mathrm{Fe}(\mathrm{III})$ in $100 \mathrm{~mL}$ of sample. The

Table 2. Influence of some foreign ions on the percent of recovery of the analytes $(\mathrm{N}=3)$

\begin{tabular}{|c|c|c|c|c|}
\hline Interfering ion & Amount of interfering $\left(\mathrm{mg} \mathrm{L}^{-1}\right)$ & Added as & Recovery of $\mathrm{Fe}(\mathrm{III})(\%)$ & Recovery of $\mathrm{Fe}(\mathrm{II})(\%)$ \\
\hline $\mathrm{Na}^{+}$ & 15000 & $\mathrm{NaNO}_{3}$ & $99 \pm 1^{\mathrm{a}}$ & $99 \pm 1$ \\
\hline $\mathrm{K}^{+}$ & 5000 & $\mathrm{KNO}_{3}$ & $100 \pm 1$ & $97 \pm 2$ \\
\hline $\mathrm{Mg}^{2+}$ & 4000 & $\mathrm{MgCl}_{2} 6 \mathrm{H}_{2} \mathrm{O}$ & $98 \pm 2$ & $99 \pm 1$ \\
\hline $\mathrm{Ba}^{2+}$ & 1000 & $\mathrm{Ba}\left(\mathrm{NO}_{3}\right)_{2}$ & $98 \pm 1$ & $98 \pm 3$ \\
\hline $\mathrm{Ca}^{2+}$ & 2000 & $\mathrm{Ca}\left(\mathrm{NO}_{3}\right)_{2} 4 \mathrm{H}_{2} \mathrm{O}$ & $98 \pm 1$ & $100 \pm 1$ \\
\hline $\mathrm{Cd}^{2+}$ & 500 & $\mathrm{Cd}\left(\mathrm{NO}_{3}\right)_{2} \cdot 6 \mathrm{H}_{2} \mathrm{O}$ & $100 \pm 2$ & $99 \pm 2$ \\
\hline $\mathrm{Sr}^{2+}$ & 1000 & $\mathrm{SrBr}_{2} 6 \mathrm{H}_{2} \mathrm{O}$ & $97 \pm 2$ & $101 \pm 1$ \\
\hline $\mathrm{Cu}^{2+}$ & 350 & $\mathrm{Cu}\left(\mathrm{NO}_{3}\right)_{2} 3 \mathrm{H}_{2} \mathrm{O}$ & $97 \pm 2$ & $96 \pm 1$ \\
\hline $\mathrm{Co}^{2+}$ & 500 & $\mathrm{Co}\left(\mathrm{NO}_{3}\right)_{2} 6 \mathrm{H}_{2} \mathrm{O}$ & $99 \pm 1$ & $98 \pm 2$ \\
\hline $\mathrm{Zn}^{2+}$ & 500 & $\mathrm{Zn}\left(\mathrm{NO}_{3}\right)_{2} 6 \mathrm{H}_{2} \mathrm{O}$ & $98 \pm 2$ & $99 \pm 2$ \\
\hline $\mathrm{Pb}^{2+}$ & 500 & $\mathrm{~Pb}\left(\mathrm{NO}_{3}\right)_{2}$ & $101 \pm 1$ & $100 \pm 2$ \\
\hline $\mathrm{Sn}^{2+}$ & 300 & $\mathrm{SnCl}_{2} 2 \mathrm{H}_{2} \mathrm{O}$ & $98 \pm 1$ & $97 \pm 2$ \\
\hline $\mathrm{Ni}^{2+}$ & 500 & $\mathrm{NiCl}_{2} 6 \mathrm{H}_{2} \mathrm{O}$ & $99 \pm 2$ & $96 \pm 1$ \\
\hline $\mathrm{Mn}^{2+}$ & 500 & $\mathrm{Mn}\left(\mathrm{NO}_{3}\right)_{2} 4 \mathrm{H}_{2} \mathrm{O}$ & $99 \pm 1$ & $100 \pm 1$ \\
\hline $\mathrm{As}^{3+}$ & 100 & $\mathrm{Na}_{2} \mathrm{AsO}_{2}$ & $97 \pm 2$ & $97 \pm 1$ \\
\hline $\mathrm{Al}^{3+}$ & 250 & $\mathrm{Al}\left(\mathrm{NO}_{3}\right)_{3} \cdot 9 \mathrm{H}_{2} \mathrm{O}$ & $98 \pm 3$ & $99 \pm 2$ \\
\hline $\mathrm{PO}_{4}{ }^{3-}$ & 400 & $\mathrm{Na}_{3} \mathrm{PO}_{4} 12 \mathrm{H}_{2} \mathrm{O}$ & $98 \pm 1$ & $101 \pm 1$ \\
\hline $\mathrm{SO}_{4}{ }^{2-}$ & 500 & $\mathrm{Na}_{2} \mathrm{SO}_{4}$ & $98 \pm 1$ & $97 \pm 2$ \\
\hline $\mathrm{ClO}_{4}^{-}$ & 500 & $\mathrm{NaClO}_{4}$ & $100 \pm 1$ & $98 \pm 3$ \\
\hline $\mathrm{SCN}^{-}$ & 150 & $\mathrm{NaSCN}$ & $99 \pm 1$ & $100 \pm 1$ \\
\hline $\mathrm{Br}^{-}$ & 2000 & $\mathrm{KBr}$ & $98 \pm 3$ & $98 \pm 2$ \\
\hline $\mathrm{Cl}^{-}$ & 8000 & $\mathrm{NaCl}$ & $99 \pm 2$ & $99 \pm 1$ \\
\hline $\mathrm{I}^{-}$ & 500 & $\mathrm{KI}$ & $97 \pm 2$ & $101 \pm 1$ \\
\hline $\mathrm{NO}_{3}^{-}$ & 40000 & $\mathrm{NaNO}_{3}$ & $100 \pm 1$ & $98 \pm 1$ \\
\hline $\mathrm{NO}_{2}^{-}$ & 30000 & $\mathrm{NaNO}_{2}$ & $97 \pm 1$ & $98 \pm 1$ \\
\hline
\end{tabular}

aMean \pm standard deviation 
Table 3. The application of the presented and reference method in real samples $(\mathrm{N}=3)$

\begin{tabular}{|c|c|c|c|c|c|c|c|c|c|}
\hline \multirow{3}{*}{ Method } & \multicolumn{9}{|c|}{ Sample } \\
\hline & \multicolumn{3}{|c|}{ drinking water $\left(\mu \mathrm{g} \mathrm{L}^{-1}\right)$} & \multicolumn{3}{|c|}{ River water $\left(\mu \mathrm{g} \mathrm{L}^{-1}\right)$} & \multicolumn{3}{|c|}{ Rain water $\left(\mu \mathrm{g} \mathrm{L}^{-1}\right)$} \\
\hline & $\mathrm{Fe}(\mathrm{III})$ & $\mathrm{Fe}(\mathrm{II})$ & Total & $\mathrm{Fe}(\mathrm{III})$ & $\mathrm{Fe}(\mathrm{II})$ & Total & $\mathrm{Fe}(\mathrm{III})$ & $\mathrm{Fe}(\mathrm{II})$ & Total \\
\hline SPE-FAAS & $73 \pm 3$ & $36 \pm 3$ & $109 \pm 2$ & $152 \pm 2$ & $87 \pm 3$ & $239 \pm 2$ & $19 \pm 3^{a}$ & - & $23 \pm 2$ \\
\hline phenanthroline & $72 \pm 2$ & $35 \pm 1$ & $107 \pm 2$ & $152 \pm 4$ & $85 \pm 2$ & $237 \pm 3$ & $<\mathrm{dl}^{\mathrm{b}}$ & $<\mathrm{dl}$ & $21 \pm 2$ \\
\hline $\mathrm{s}_{\mathrm{p}}$ & 2.55 & 2.24 & 2 & 3.16 & 2.55 & 2.55 & - & - & 2 \\
\hline$\Delta \mathrm{x}_{\exp }$ & 1 & 1 & 2 & 0 & 2 & 2 & - & - & 2 \\
\hline$\Delta \mathrm{x}_{\text {min cri }}$ & 5.78 & 5.0 & 4.53 & 7.17 & 5.78 & 5.78 & - & - & 4.53 \\
\hline
\end{tabular}

${ }^{\mathrm{a}}$ Mean \pm standard deviation, ${ }^{\mathrm{b}}$ Below detection limit, At $95 \%$ confidence level, Degree of freedom $=6-2, \Delta \mathrm{x}_{\min }$ cri $= \pm \mathrm{ts}_{\mathrm{p}}\left(\mathrm{n}_{1}+\mathrm{n}_{2} / \mathrm{n}_{1} \times \mathrm{n}_{2}\right)^{1 / 2}, \Delta \mathrm{x}_{\text {exp }}=\mathrm{x}_{1}-\mathrm{x}_{2}$.

relative standard deviation (RSD) was $2.1 \%$.

The limit of detection LOD of the proposed method for the determination of iron(III) was studied under optimal experimental conditions. The detection limits were expressed as the amount of analyte in $\mu \mathrm{g} \mathrm{L}^{-1}$ giving a signal-to-noise ratio of 3. The LOD obtained from $\mathrm{C}=\mathrm{K}_{\mathrm{b}} \mathrm{S}_{\mathrm{b}} \mathrm{m}^{-1}$ for a numerical factor of $\mathrm{K}_{\mathrm{b}}=3$, was $2.8 \mu \mathrm{g} \mathrm{L}^{-1}$. The maximum capacity of the disk obtained from three replicate measurements was $100 \pm 3 \mu \mathrm{g}$ of $\mathrm{Fe}$ (III) on the disk. In addition, the disk was stable for 3 runs using $100 \mathrm{~mL}$ of sample solution.

\section{Analysis of the natural water samples}

The proposed method was applied to the speciation and determination of $\mathrm{Fe}$ (III) and $\mathrm{Fe}$ (II) from $100 \mathrm{~mL}$ water samples from white river water (Lahijan, Iran), rain water (Iran) and drinking water (Sanandaj, Iran). The results obtained are shown in Table 3 and compared with those obtained by the standard spectrophotometric method. ${ }^{28}$ As shown in Table 3, the results obtained by solid-phase extraction are in satisfactory agreement with those obtained by the spectrophotometric standard method.

\section{Analysis of powdered milk}

A $5.00 \mathrm{~g}$ amount of powdered milk was weighed in a platinum crucible, and placed into a muffle furnace at a temperature of $300{ }^{\circ} \mathrm{C}$ for an hour. When charring was complete, the temperature was gradually raised to $500-550{ }^{\circ} \mathrm{C}$ and the sample ashed over night until becoming a grayish white color. The ashed samples were removed from the furnace and allowed to cool, and then $5 \mathrm{~mL}$ of $\mathrm{HCl}(1+1)$ was added. The sample was then covered with a watch glass and gently boiled for $5 \mathrm{~min}$. When the crucible and watch glass had cooled, the watch glass was removed, and any droplets formed on it were washed into the crucible with redistilled water. ${ }^{29}$ After adjusting the $\mathrm{pH}$, analysis was done as outlined previously, the results of which are shown in Table 4 . The data in Table 4 demonstrates good agreement
Table 4. Analytical results of total iron in powder milk

\begin{tabular}{lcccc}
\hline \multirow{2}{*}{ Sample } & \multicolumn{2}{c}{ Fe determined $(\mathrm{mg}$ in $100 \mathrm{~g})$} & & \\
\cline { 2 - 3 } & SPE-FAAS & 1,10 phenanthroline & & \\
\hline Powdered milk & $5.69 \pm 0.04$ & $5.76 \pm 0.07$ & 0.07 & 0.14 \\
\hline
\end{tabular}

At $95 \%$ confidence level, $\mathrm{N}=3$, Degree of freedom $=6-2$,

$\Delta \mathrm{x}_{\text {min cri }}= \pm \mathrm{ts}_{\mathrm{p}}\left(\mathrm{n}_{1}+\mathrm{n}_{2} / \mathrm{n}_{1} \times \mathrm{n}_{2}\right)^{1 / 2}, \Delta \mathrm{x}_{\text {exp }}=\mathrm{x}_{1}-\mathrm{x}_{2}$.

between the results obtained for the proposed method and the standard spectrophotometric method.

\section{Comparison of method with other systems}

The comparative information from some recent studies on preconcentration of $\mathrm{Fe}^{3+}$ is given in Table 5. As can be seen, in comparison with the other reported methods, the present method showed a comparatively high linear dynamic range (40.0-1000.0 $\mu \mathrm{g} \mathrm{L}^{-1}$ ) and a higher enrichment factor (166) with a good limit of detection $\left(2.8 \mu \mathrm{g} \mathrm{L}^{-1}\right)$ for iron speciation in a short time frame.

\section{CONCLUSION}

The results of the present investigation demonstrate the utility of octadecyl silica membrane disk modified with new synthetic ligand for the separation and speciation of $\mathrm{Fe}$ (III) and Fe(II). The separated $\mathrm{Fe}$ (III) was subsequently measured by FAAS. Iron (II) was determined by difference in measurements after oxidation of iron(II) to iron(III) by $\mathrm{HNO}_{3} \cdot{ }^{13}$ The method described allows the determination and speciation of iron in water samples, compared with the standard method - that directly determines iron(II) concentration which can be at low concentrations in water samples. Fe(III) concentration is determined by subtraction of the Fe(II) from total iron. In the present work, the Fe(III) was measured directly and Fe(II) calculated by the difference. The two methods (standard and present) are therefore,

Table 5. Characteristic performance data obtained by using the proposed and other reported methods for iron determination

\begin{tabular}{|c|c|c|c|c|c|c|}
\hline Method & $\operatorname{LDR}\left(\mu \mathrm{g} \mathrm{L}^{-1}\right)$ & $\mathrm{R}^{2}$ & $\mathrm{RSD} \%$ & Concentration factor & $\operatorname{LOD}\left(\mu \mathrm{g} \mathrm{L}^{-1}\right)$ & Ref. \\
\hline Present Method & 40- 1000 & 0.999 & 2.1 & 166 & 2.8 & This work \\
\hline SPE ${ }^{\mathrm{a}}-\mathrm{FAAS}$ & $20-1000$ & 0.997 & - & 71 & 19 & 13 \\
\hline $\mathrm{CPE}^{\mathrm{b}}$-FAAS & $10-250$ & 0.999 & 2.1 & 75 & 1.7 & 30 \\
\hline SPE-FAAS & - & - & $<10$ & 60 & 11 & 31 \\
\hline SPE-FAAS & $20-350$ & - & 2.3 & 24 & 2.3 & 19 \\
\hline SPE-FAAS & - & - & 1.7 & 166 & 0.63 & 32 \\
\hline SPE-FAAS & $250-5000$ & 0.999 & 3.7 & 62 & 0.82 & 33 \\
\hline
\end{tabular}

a Solid phase extraction, ${ }^{\mathrm{b}}$ cloud point extraction. 
complimentary. ${ }^{13}$ The advantages of the proposed method, based on the results presented in this study, can be summarized by the following points:

- the DAHPB reagent was found to be a powerful extractant for the selective extraction of $\mathrm{Fe}(\mathrm{III})$ ions;

- the method is simple, reproducible, selective and rapid;

- the method determines concentrations of iron(III) directly, usually present at a higher concentration in water samples;

- the separation of Fe(III) from potential interferences is possible at $\mathrm{pH} 2.5$, such as strong oxidizing agent, nitrite, phosphates, zinc, cobalt, copper, nickel, bismuth, cadmium, mercury and silver so that these ions do not cause any interference. Therefore, the presented procedure seems less prone to interferences than the standard method and may be used as an alternative for those samples in which the standard method is not applicable;

- the presented method is applicable to samples with a mole ratio of $\mathrm{Fe}$ (III) / $\mathrm{Fe}$ (II) varying across a wide range (from 0:10 to 10:0).

\section{REFERENCES}

1. Cornelis, R.; Caruso, J.; Crews, H.; Hramann, K; Handbook of Elemental Speciation II, Species in the Environment, Food, Medicine and Occupational Health, John Wiley \& Sons, 2005.

2. Martin, J. H.; Fitzwater, S. E.; Nature 1988, 331, 341.

3. Martin, J. H.; Gordon, R. M.; Broenkow, S. E.; Fitzwater. W.W.; Deep Sea Res. Part A 1989, 36, 649.

4. Pu, X.; Hu, B.; Jiang, Z.; Huang, C.; Analyst 2005, 130, 1175.

5. Achterberg, E. P.; Holland, T. W.; Bowie, A. E.; Fauzi, R.; Mantroura, C.; Worsfold, P. J.; Anal. Chim. Acta 2001, 442, 1.

6. Aki, M. A.; Microchem. J. 2003, 75, 199.

7. Kara, D.; Alkan, M.; Talanta 2001, 55, 415.

8. Yaman, M.; Kaya. G.; Anal. Chim. Acta 2005, 540, 77.

9. Xiong, C.; Jiang, Z.; Hu, B.; Anal. Chim. Acta 2006, 559, 113.

10. Pournghi-Azar, M. H.; Fatemi, B. M.; Microchem. J. 2000, 65, 199.
11. Ensafi, A. A.; Chamjangali, M. A.; Mansur, H. R.; Anal. Sci. 2004, 20, 645.

12. Croot, R. L.; Johansson, M.; Electroanalysis 2000, 8, 565.

13. Pehlivan, E.; Kara, D.; Microchim. Acta 2007, 158, 137.

14. Ashdown, R. P.; Marriot, P. J.; J. High Resolut. Chromatogr. 2000, 23 , 430 .

15. Tuzen. M.; Melek. E.; Soylak. M.; J. Hazard. Mater. 2008, 159, 335.

16. Samaci, S.; Kartal, S.; Anal. Chim. Acta 2008, 623, 46.

17. Sussulini, A.; Arruda, M. A. Z.; Eclet. Quim. 2006, 31,73.

18. Khayatian, G.; Ahmadzadeh Vosta Kolaie, H.; Nasiri, F.; Atashkar, B.; Hassanpoor, S.; J. Chin. Chem. Soc. 2010, 57, 118.

19. Marahel, F.; Ghaedi, M.; Montazerozohori, M.; Nejati Biyareh, M.; Nasiri Kokhdan, S.; Soylak, M.; Food. Chem. Toxicol. 2011, 49, 208.

20. Puri, B. K.; Wasey, A.; Katyal. M.; Microchim. Acta 1989, 99, 17.

21. Bag, H.; Turker, A. R.; Tunceli, A.; Lale, M.; Anal. Sci. 2001, 17, 901.

22. Khayatian. G.; Karoonian, F. S.; Vaziri, S; Polish. J. Chem. 2008, 82, 537.

23. Khayatian, G.; Shariati, S.; Shamsipur. M.; J. Incl. Phenom. 2003, 45, 117.

24. Hasani, M.; Shamsipur, M.; J. Incl. Phenom. 1993, 16, 123.

25. Jabbari, A.; Hasani, M.; Shamsipur, M.; J. Incl. Phenom. 1993, 15, 329.

26. Zoltov, Y. A.; Extraction of Chelate Compounds, Ann Arbon-Humphery: London, 1970.

27. Morrison, G. H.; Freiser, H.; Solvent Extraction in Analytical Chemistry, John Wiley: London, 1966.

28. Franson, M. A. H.; Standard Method for Examination of Water and Waste Water, American Publication Health Association, 1995.

29. Pyenson, H.; Tracy, P. H.; J. Dairy. Sci. 1945, 28, 401.

30. Shakerian, F.; Dadfarnia, S.; Haji Shabani, A. M.; J. Iran. Chem. Soc. 2009, 6, 594.

31. Saracoglu, S.; Elci,L.; Anal.Chim. Acta 2002, 452, 77.

32. Khayatian, G.; Pouzesh, S.; J. Iran. Chem. Soc. 2007, 4, 490.

33. Yıldız, O.; Citak, D.; Tuzen, M.; Soylak, M.; Food. Chem. Toxicol. 2011, $49,458$. 